International Journal of Social Sciences and Humanities
Available online at http://sciencescholar.us/journal/index.php/ijssh
Vol. 3 No. 2, August 2019, pages: 302 308
e-ISSN: 2550-7001, p-ISSN: 2550-701X
https://doi.org/10.29332/ijssh.v3n2.340

\title{
Cooperative Principle Implementation between Teachers and Students: Indonesian Language Teaching Case
}

\author{
Dewa Ayu Widiasri a, Made Budiarsa ${ }^{b}$, Nengah Sudipa ${ }^{c}$, Made Sri Satyawati ${ }^{\mathrm{d}}$
}

Article history: Received 09 January 2019, Accepted: 30 April 2019, Published: 31 August 2019

\section{Correspondence Author ${ }^{\text {a }}$}

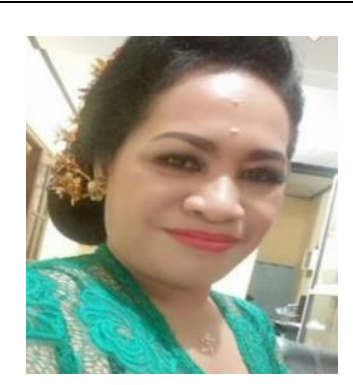

Keywords

cooperative principle;

Indonesian;

interaction;

learning;

maxim:

\begin{abstract}
This research aimed to explain the context of learning by applying the principles of cooperation during the teaching and learning process in the classroom, and the relationship of working principles between teachers and students. This study used a qualitative descriptive approach. The research subjects were Indonesian language teachers and students in Tampaksiring Senior High School 1. To gain data, the methods of recording, observation, and interview were applied. Data analysis was conducted with three stages of analysis, namely the stage of data collection, the stage of data verification, and the stage of drawing conclusions. The results showed that the application of the principle of cooperation was influenced by the context in the teaching and learning process, and was dominated by formal situations. In the principle of cooperation, the teacher and student are dominated by quantity maxim, quality maxim, relevance maxim, and manner maxim. It is concluded that by applying the principle of cooperation, especially in Indonesian learning, an atmosphere of effective and efficient teaching and learning will be built.
\end{abstract}

e-ISSN: 2550-7001, p-ISSN: 2550-701X ${ }^{\odot}$ Copyright 2019. The Author. SS Journals Published by Universidad Técnica de Manabí. This is an open-access article under the CC BY-SA 4.0 license (https://creativecommons.org/licenses/by-sa/4.0/) All rights reserved.

\section{Contents}

Abstract

1. Introduction 303

2. Materials and Methods 304

3. Results and Discussions

3.1 Representation of Quantity Maxims..

3.2 Representation of Quality Maxims.

3.3 Representation of the Maxim of Manner 305

a IKIP PGRI Bali, Denpasar, Indonesia

b Udayana University, Denpasar, Indonesia

c Udayana University, Denpasar, Indonesia

d Udayana University, Denpasar, Indonesia 


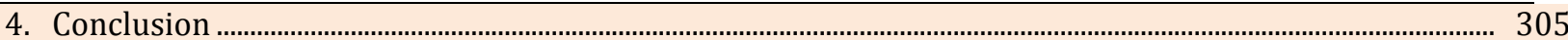

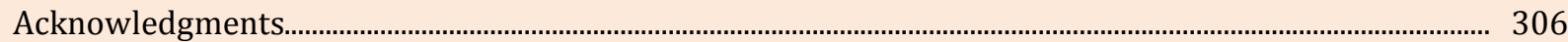

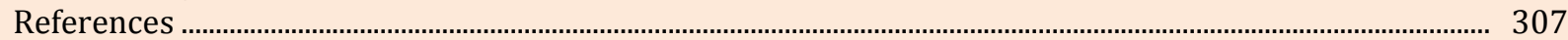

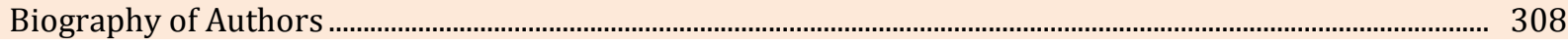

\section{Introduction}

Language is a medium of communication. Being able to communicate cannot be used as a benchmark for someone to be successful in communicating. There are situation and context factors affecting the use of language. This factor is played by Pragmatics in language events since the communication itself is not just language, but the way language is used is based on the situation and context so that the language events between the speaker and the speech partner occur properly (Latupeirissa \& Sayd, 2019).

In learning Indonesian, Pragmatics is used by teachers in the interaction of teaching and learning. This approach is often used because it is very communicative so that communication runs well in the classroom. The purpose of this approach is not only for mastery of vocabulary, but the communicative ability between students and teachers in achieving learning goals. According to Leech (1993), Pragmatics is the science of how language is used in communication. This opinion greatly contributes in applying the relevant Pragmatic theory with the communicative function in the teaching and learning process. The communicative function is closely related to cooperation. According to Grice, cooperation in interacting must use speech that is informative, true, relevant, concise, not cryptic and ambiguous so that the data information is received by the speech partner correctly, relevant, and clear. The principle of Grice cooperation includes four maxims, namely the quality maxim, the maxim of quantity, the maxim of relevance, and the way of maxim. (1) Maximum quantity is the maximum contribution to make a contribution or contribution as informative as possible as needed and not allowed to make a contribution in excess of what you are requested. (2) quality maxims are maxims that do not allow saying what is believed to be wrong and say something that has no proof. (3) the maxim of relevance is the maxim giving advice to the speaker to say what is relevant or related to being cooperative. (4) method maxim is a maxim that avoids the ambiguity of expressions and ambiguities (Attardo, 1993; Lindblom, 2001). Short and organized. These four principles of collaboration are used to explain the interaction between the teacher and students in the class so that they can create an effective and efficient learning environment.

Relevant research functions to provide differences and similarities about previous researches that have been conducted. Here are some relevant studies. First, Lindblom (2001), that conducted study under the title "Cooperating with Grice: A cross Disciplinary Metapplective on uses of Grice's cooperative principle". Lindblom (2001), uses metaphor perspective with three units of analysis, such as speech, social interaction, and social context. The results of the three units of analysis found that the maxim was flexible in the context of the discourse and described the discourse as utterance and social interaction. Interdisciplinary contains collaboration theory between Grice Maxim as well as Brown \& Lavinson (1978), that is by focusing on speech analysis. With this collaboration, it is explained that discourse is social interaction and a social context (see Latupeirissa et al., 2019). Equation of research Lindblom (2001) with this research lies in the unit analysis stage. Lindbloom uses speech as a source of data to explain social interactions and social contexts, while differences exist in research methods. Lindblom uses random methods to analyze utterances, while this study uses the recording method, observation method, and interview method.

Secondly, Zhou (2009), titled "cooperative principle in oral English teaching 'aims to improve the ability of English and students' communication skills. By using the principle of cooperation Grice, teachers and students are more directed in communication. The difference between Zhou (2009) and this research lies in the object of his study. Zhou's research uses oral English teaching as the object of his study, while this study uses the interaction of students and teachers in learning Indonesian. The research equation of Zhou (2009), lies in the theory applied, which is the same as using the theory of Grice maxim to explain utterances produced during the teaching and learning process.

Thirdly, Sari (2014), entitled The Implementation of the Principles of Cooperation in Teacher and Student Conversations and Their Impact on Indonesian Language Learning in Class XI of SMAN 1 Kediri. Sari (2014), explains the illustrations of teacher and student conversations in learning Indonesian. His research uses descriptive quality with the recording method, observation method, and interview method. Sari's research

Widiasri, D. A., Budiarsa, M., Sudipa, I. N., \& Satyawati, M. S. (2019). Cooperative Principle Implementation between Teachers and Students. International Journal of Social Sciences and Humanities, 3(2), 302-308. https://doi.org/10.29332/ijssh.v3n2.340 
results show that teachers and students adhere to each of the four maxims proposed by Grice. With the application of the principle of cooperation to give an impact on students being comfortable in class and achieving learning targets The difference between Sari (2014), and this research lies in the research subject, namely Sari's research using research subjects in class IX of SMAN 1 Kediri while the research uses research subjects in class X of SMAN 1 Tampaksiring-Bali. The equation lies in the theory and the method used, that is both using the principle of Grice's cooperation principle and the recording method, the observation method, and the interview method.

Based on the above background, several problems were formulated, namely (1) how the application of the principle of cooperation by the teacher, and (2) how the learning context is relevant to the teaching and learning process, especially in learning Indonesian.

\section{Materials and Methods}

This research applies the principle of cooperation in the interaction between teachers and students towards the learning of Indonesian language is the study of language phenomena using interaction in the classroom. To examine this research is relevant to the qualitative descriptive approach. The language phenomenon aims to explain the phenomenon of language during the interaction of teachers and students occurs in the teaching and learning process in class (2007: 68-69). The subjects of this study were students and teachers of Indonesian language class X SMAN 1 Tampaksiring_-Bali. This study uses three data collection methods, namely record, observation, and interview (Sudaryanto, 2015). The recording method is used to record interactions between the teacher and students in the classroom, then the results of the record are transcribed into Indonesian in the form of utterances. The utterances are observed and grouped into utterances which are included in the principle of cooperation. To support the results of the record and the results of the observation conducted an interview method so that the data obtained is more valid and measurable.

\section{Results and Discussions}

\subsection{Representation of Quantity Maxims}

The representation of quantity maxims can be seen in the following data.

Teacher : There are types of books Who knows the definition of a reviewer?

Student : Fiction and non-fiction

Teacher : What is fiction?

Student : True story

Teacher : Think again

[Speech 1]

It was happening when the teacher explains Indonesian learning material about book reviews and the teacher encourages students to answer questions from the teacher about the types of reviews. The teacher is able to stimulate by asking students to participate actively in the learning process, but as if the student is not ready to answer the questions given by the teacher about the reviewer.

Speech (1) contains a maxim of quantity because the teacher tries to be cooperative in providing subject matter to students about book reviews. Speech (1) also has a modest contribution spoken by the teacher and students. However, students respond was not as expected by the teacher. In maxim of quantity, the teacher was adequate in communicating learning. Although students were not ready in the learning process. Whereas the teacher had given the task of reading about book reviews. Students' answers should be 'not real stories' definitions of non-fiction. In order for the principle of maximum quantity cooperation to be carried out well, it is better for the teacher to evaluate students who did not read about book reviews before the lesson began. Teachers should provide a kind of punishment to students who do not read books so that students' answers 
when asked about book reviews are more adequate and contribute. This will make the teaching and learning process more effective and smooth.

\subsection{Representation of Quality Maxims}

Next, the following is the data of speech 2 that was based to describe other findings.

$\begin{array}{lll}\text { Teacher } & : & \text { Who still remembers about reviewing book? } \\ \text { Student } & : & \text { To pros and cons of a work } \\ \text { teacher's } & : & \text { What is the purpose of making a review? } \\ \text { Student } & : & \text { Reader } \\ \text { Teacher's } & : & \text { Good }\end{array}$

[Speech 2]

The conversation was held in class X 3 IPS 4. When the teacher explained the book review in class, the teacher encourages students to answer questions. It is intended that students take an active role in the teaching and learning process.

Speech (2) contains maxims of quality because the teacher tries to provide a little stimulation about the definition of book references and their uses. In Speech (2), students give answers that are considered correct by the teacher. Students believe the answers given are based on students' knowledge of reading book resources about book reviews obtained from the teacher. Students' answers are correct that the answer 'book review is to assess the merits of a work'. With these answers, the teacher gives a good response. It can be assumed that the students' answers to gurur questions meet the maximum quality and are in accordance with Indonesian learning outcomes. Thus, speech (2) is an embodiment of the principle of maxim quality cooperation and makes the teaching and learning process more comfortable and efficient.

\subsection{Representation of the Maxim of Manner}

Data 3 that is presented as follows indicates that there is a maxim of manner in the conversation.

$$
\begin{array}{lll}
\text { Teacher } & : \text { Writing reviews should be done in groups } \\
\text { Students } & : \text { Ok Mom }
\end{array}
$$

[Speech 3]

It was happening when the teacher explains about book reviews in class, the teacher advises students to write reviews in groups. Speech markers advise 'should'. Speech 3 is an advising speech with an advising marker, which is best a marker should remind students to work on book reviews in groups. This aims to stimulate students to actively participate in groups in working on assignments given by the teacher.

Speech (3) contains the maxim of manner because there is a way desired by the teacher to create groups and work on book reviews. Speech 3) can be heard and understood clearly by students. This is evidenced by the actions of students by finding and forming groups. It can be said that speech (3) has a good response from students on the instructions given by the teacher to make a group. Speech (3) is a representation of the principle of maximal cooperation in a way that the teaching and learning process in the classroom runs effectively and efficiently.

\section{Conclusion}

Based on the results of data analysis, it can be concluded that the application of the principle of cooperation in interaction with Indonesian language learning in class X of SMAN 1 Tampaksiring includes adherence to the principle of cooperation. In the application, the principle of cooperation found and dominated by 3 maxims out of 4 maxims (as proposed by Grice (1975), namely the quality maxim, quantity maxim, and method maxim). Speech (1) until speech (3) was an embodiment of the principle of cooperation so that the learning process can

Widiasri, D. A., Budiarsa, M., Sudipa, I. N., \& Satyawati, M. S. (2019). Cooperative Principle Implementation between Teachers and Students. International Journal of Social Sciences and Humanities, 3(2), 302-308.

https://doi.org/10.29332/ijssh.v3n2.340 
run efficiently and effectively. With the application of the principle of cooperation in the learning process, it cannot be separated from the context of speech events in the classroom. This greatly influences the situation in the teaching and learning process so that the learner's goals can be achieved clearly (Widiasri et al., 2019; Suparsa, 2017).

Acknowledgments

We would like to thank LPDP who have funded this research. 


\section{References}

Attardo, S. (1993). Violation of conversational maxims and cooperation: The case of jokes. Journal of pragmatics, 19(6), 537-558. https://doi.org/10.1016/0378-2166(93)90111-2

Brown, P., \& Levinson, S. C. (1978). Universals in language usage: Politeness phenomena. In Questions and politeness: Strategies in social interaction (pp. 56-311). Cambridge University Press.

Grice, H. P. (1975). " Logic and conversation" In Cole, P., and Morgan, J.(Eds.). Syntax \& Semantics, 3.

Latupeirissa, D. S., \& Sayd, A. I. (2019). Grammatical errors of writing in EFL class. International journal of linguistics, literature and culture, 5(2), 1-12. https://doi.org/10.21744/ijllc.v5n2.605

Latupeirissa, D. S., Laksana, I. K. D., Artawa, K., \& Sosiowati, I. G. A. G. (2019). On Political Language Ideology: Critical View of Indonesian President Speech. Journal of Language Teaching and Research, 10(4), 843-850. http://dx.doi.org/10.17507/jltr.1004.23

Leech, G. (1993). Prinsip-prinsip Dasar Pragmatik.

Lindblom, K. (2001). Cooperating with Grice: A cross-disciplinary metaperspective on uses of Grice's cooperative principle. Journal of Pragmatics, 33(10), 1601-1623. https://doi.org/10.1016/S03782166(00)00069-2

Sari, S. (2014). Improving speaking skills through cooperative learning for the vii grade students of smp $\mathrm{n} 2$ berbah in the academic year of 2013/2014. Unpublished Undergraduated Thesis. Yogyakarta State University.

Sudaryanto, D. P. (2015). Metode dan aneka teknik analisis Bahasa [Method and technique of language study].

Suparsa, I. N., Mantra, I. B. N., \& Widiastuti, I. A. M. S. (2017). Developing learning methods of Indonesian as a foreign language. International Journal of Social Sciences and Humanities, 1(2), 51-57. https://doi.org/10.29332/ijssh.v1n2.41

Widiasri, D. A., Budiarsa, M., Sudipa, I. N., \& Satyawati, M. S. (2019). Speech act in Indonesian language teaching: an ethnography communication study. International journal of linguistics, literature and culture, 5(5), 55-62. https://doi.org/10.21744/ijllc.v5n5.740

Zhou, M. (2009). Cooperative Principle in Oral English Teaching. International education studies, 2(3), $42-46$.

Widiasri, D. A., Budiarsa, M., Sudipa, I. N., \& Satyawati, M. S. (2019). Cooperative Principle Implementation between Teachers and Students. International Journal of Social Sciences and Humanities, 3(2), 302-308. 


\section{Biography of Authors}

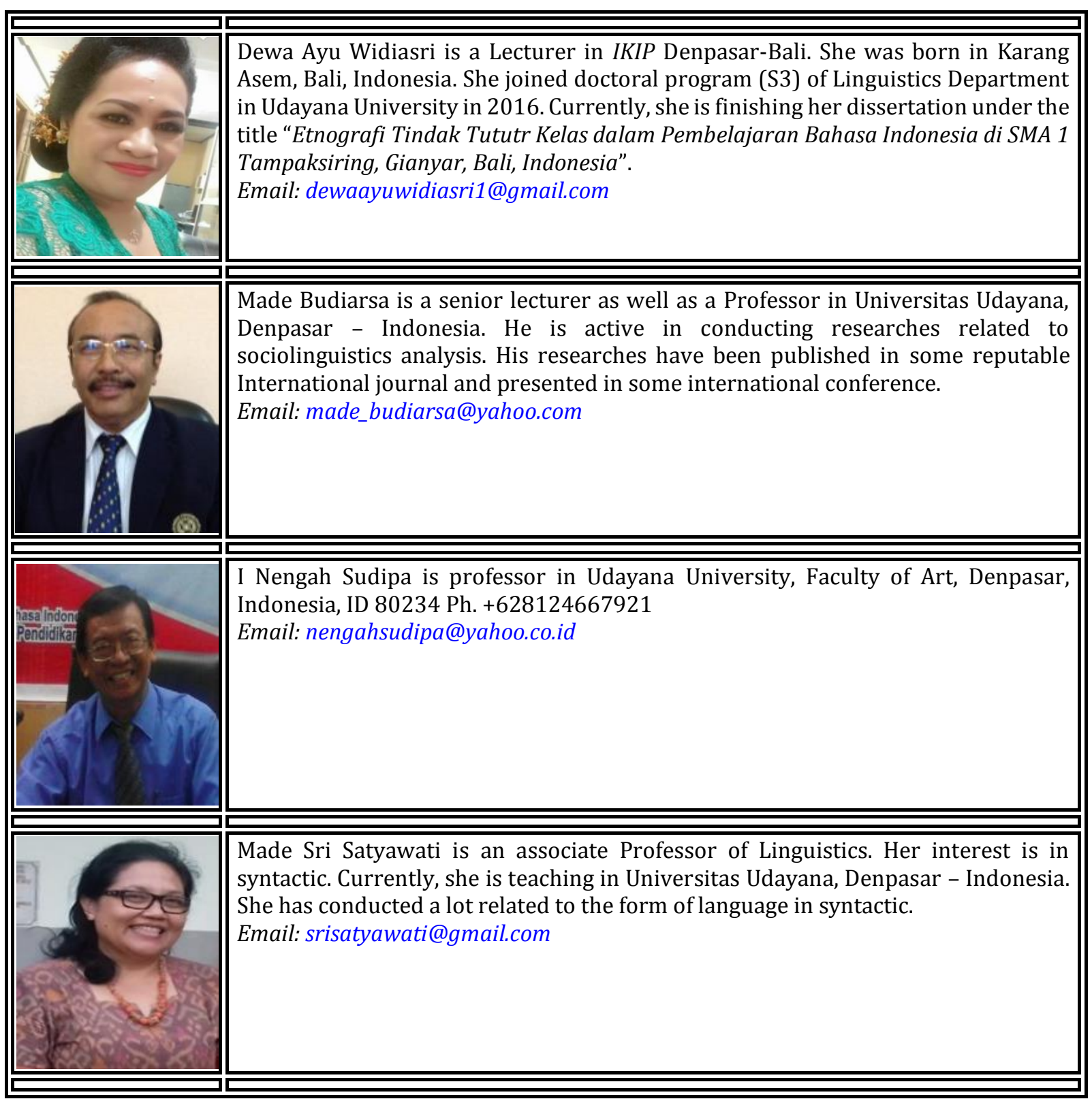

